\title{
The Right to be Free from Trial: Comments on "State of Missouri V. Darren Wilson"
}

\author{
OU Yuanjie \\ Ph.D in Law, No.59 Zhongguancun Street, Renmin University, 100872 Beijing, P.R. China. \\ *Corresponding Author: OUYuanjie, Ph.D in Law, No.59 Zhongguancun Street, Renmin University, \\ 100872 Beijing, P.R. China

\begin{abstract}
In the trial of the case of "State of Missouri v. Darren Wilson", the grand jury in the Missouri of the United States undertook tremendous pressure from the public. The grand jury finally found that there was no reasonable basis for suing the "possible defendants" and decided not to grant Prosecution, although this decision apparently will trigger a new round of controversy. In a general sense, the concept that the accused is entitled to a fair trial is already well-established, but perhaps another basic right of a citizen is of equal importance, that is the right to be free from trial. Not to prosecute or not to be judged by the court, which reflects the maintenance on the substantive interests and procedural interests of individuals. However, if there is turbulent public opinions or even "blackmailing", it is a great challenge for the court to stick to its responsibility.
\end{abstract}

Keywords: "State of Missouri V. Darren Wilson"; The Grand Jury; Self-Defense

\section{THE BASIC FACTS}

At 11:51 AM on August 9, 2014, a convenience store in the West Ferguson was looted and the video camera at the convenience store showed Michael Brown ("Brown") taking a box of cigars and using violence against his staff. At about 11:53, Darren Wilson, a Ferguson Police Constable who is handling an emergency, heard the robbery broadcast, whichdescribes the basic characteristics of the suspects.

When Wilson drove west of Canfield, he saw Brown and his companion Dorian Johnson ("Johnson") walking in the center of Canfield Road. Wilson told them to go back to the sidewalk, but they did not do it. Wilson observed that Michael Brown had cigarillos in his hand and was wearing a red hat. At approximately 12:02 p.m., Wilson radioed he had to individuals on Canfield and needed assistance. Officer Wilson backed his vehicle at an angle blocking their path and blocking the flow of traffic in both directions.

An altercation took place with Officer Wilson seated inside the vehicle and Mr. Brown standing at the drivers window. During the altercation, two shots were fired by Officer Wilson while still inside the vehicle. Mr. Brown ran east and Officer Wilson gave chase. Near the corner of Canfield and Coppercreek, Mr. Brown stopped and turned back to Officer Wilson. Officer Wilson also stopped. As Michael Brown moved towards Officer Wilson, several more shots were fired by the officer and Michael Brown was fatally wounded. Brown fell to the ground 153 feet (46.6 meters) from the police car.

A grand jury in St. Louis County, Missouri, conducted a 115-days investigation of the Missouri v. Darren Wilson case (the "Wilson case"), which the jury heard over 70 hours of testimony from about 60 witnesses. They tooka review of the physical evidence and reports of experts in the fields of medicine, DNA, firearms and more, and got access to hundreds of photographs. On November 24, 2014, Robert McCulloch, prosecutor of St. Louis County of Missouri, announced the not-to-beprosecuted decision of the grand jury. He also announced a partial physical evidence and witness testimony that have been presented to grand jury.

\section{INSTITUTIONAL BACKGROUND AND NORMATIVE BACKGROUND}

\subsection{Introduction of the Grand Jury System}

The American grand jury usually has between 5-23 members (12 grand juries in Missouri). In most 
jurisdictions, the grand jury members are selected in the same way as a jury: Members of the Grand Jury are randomly selected from among those eligible candidates; selected members deal with a number of cases that may lead to public prosecution within a certain time period. Unlike ordinary juries, which is more familiar to us, the grand jury in the United States decides whether or not to prosecute a "possible defendant". And this kind of citizen participation in prosecutors' prosecution is considered as a way to review the right of the prosecutors. In contrast, the ordinary jury is in the trial proceedings to judge whether the defendant guilty or not. It is generally assumed that grand juries have the dual function of investigating evidence and examining prosecutions, with corresponding special authorities and procedures.

\subsubsection{Grand Jury in Federal law System}

The Fifth Amendment to the United States Constitution provides that "No person shall be held to answer for a capital, or otherwise infamous crime, unless on a presentment or indictment of a Grand Jury, except in cases arising in the land or naval forces, or in the Militia, when in actual service in time of War or public danger . ..." Misdemeanors are not presented to a grand jury, and are instead charged by prosecutor's "information." In the United States armed forces, an Article 32 hearing is used for a similar purpose. The grand jury right may be waived, including by plea agreement. A valid waiver must be made in open court and after the defendant has been advised of the nature of the charge and of the defendant's rights.

Rule 6 of the Federal Rules of Criminal Procedure governs grand juries. It requires grand juries to be composed of 16 to 23 members and that 12 members must concur in an indictment. A grand jury is instructed to return an indictment if the probable cause standard has been met. The grand jury's decision is either a "true bill" (formerly billa vera, resulting in an "indictment"), or "no true bill".

Grand jury proceedings are secret. No judge is present; the proceedings are led by a prosecutor; and the defendant has no right to present his case or (in many instances) to be informed of the proceedings at all. While court reporters usually transcribe the proceedings, the records are sealed. The case for such secrecy was unanimously upheld by the Burger Court in Douglas Oil Co. of Cal. v. Petrol Stops Northwest, 441 US 211 (1979). The dissenting opinion was joined by Justices Burger and Stewart but concurred with the Court's opinion as to the importance and rationale of grand jury secrecy. Writing for the Court, Justice Powell found that "if preindictment proceedings were made public, many prospective witnesses would be hesitant to come forward voluntarily"; "witnesses who appeared before the grand jury would be less likely to testify fully and frankly"; and "there also would be the risk that those about to be indicted would flee, or would try to influence individual grand jurors". Further, "persons who are accused but exonerated by the grand jury should not be held up to public ridicule".

United States v. Procter \& Gamble Co., 356 US 677 (1958), permitted the disclosure of grand jury transcripts under certain restrictions: "a private party seeking to obtain grand jury transcripts must demonstrate that 'without the transcript a defense would be greatly prejudiced or that without reference to it an injustice would be done"' and must make its requests "with particularity". Further, First Amendment protections generally permit the witnesses summoned by a grand jury to discuss their testimony, although Dennis v. United States, 384 US 855 (1966), found that such public discussion permits release of the transcripts of their actual testimony.

The Jencks Act, 18 U.S.C. $§ 3500$, requires the government to disclose to the defense any statements made by the accused to the grand jury, and, with respect to non-party witnesses, that after a witness has testified on direct examination at trial, any statement made to the grand jury by such witness be disclosed to the defense.

United States law also provides for the formation of special grand juries. While a regular grand jury primarily decides whether to bring charges, a special grand jury is called into existence to investigate whether organized crime is occurring in the community in which it sits. This could include, for instance, organized drug activity or organized corruption in government. As provided in 18 U.S.C. § 3331(a), the U.S. District Court in every judicial district having more than four million inhabitants must impanel a special grand jury when requested by a designated official of the Justice Department.

Due to the criticism against the federal grand jury system there are some reform proposals which include the following proposals: (1) Better instructions from judges to jurors about the grand jury's 
powers and its independence from prosecutors. (2) Increased access to grand jury transcripts for suspects who are eventually indicted. (3) Expanded safeguards against abuse of witnesses, including education about their rights and the presence of their attorneys. (4) Notification of targets of investigations that they are targets. (5) Optional rather than mandatory appearances by targets of investigations. (6) An end to the requirement that prosecutors present defense evidence, and replacement with a requirement that grand jurors be informed that the defense was not represented in the hearing.

\subsubsection{The Function of Investigating Evidence}

The special powers of the grand jury to investigate the evidence lie, first and foremost, in the mandatory summoning of witnesses. According to the law, anyone who is summoned by a grand jury must testify before court, while refusing to testify to a grand jury will be sentenced as contempt of court. Normally, the grand jury summons only one to two witnesses - the victim (if any) and the police who is handling the case. Secondly, grand jury trials are not subject to the Exclusionary Rules of Illegal Evidence, which takes into account that grand jury hearings are not criminal or non-criminal. Thirdly, only prosecutor could present evidence to the grand jury, the individuals who might face the prosecution might not have the right to testify or produce evidence to the grand jury, nor would there be evidence of cross-examination of the prosecution. This would bring the result that evidence is usually entirely controlled by the prosecutor. Finally, unlike court trials, the process of grand jury investigation and decision-making is confidential. Only jury members, prosecutors and summoned witnesses are allowed to stay in the grand jury rooms. This is mainly to ensure that witnesses feel free to state and take the reputation of "possible defendants" into account. Under Missouri law, a grand jury member who violates confidentiality rules constitutes a level 1 misdemeanor. ${ }^{1}$

\subsubsection{The Function of Reviewing the Prosecution}

Whether the grand jury system is adopted and the system's implementation are governed by the laws of each state. Currently, U.S. federal law and about one-half of the states state that felony cases must be reviewed by a grand jury before prosecution.

The grand jury examines the indictment, that is, examines if there is a reasonable basis for the commission of the crime and "possible defendant" is the perpetrator of the case. The grand jury does not judge the guilt problem of a particular person. Even if the grand jury decides to prosecute, it does not mean that the "possible defendant" is guilty of the crime. It merely represents that he must bear the trial. Accordingly, a grand jury may decide on a prosecution only if a probable cause indicates a crime, a standard that is significantly lower than the "excluding reasonable suspicion" of establishing a crime. And if the grand jury does not find a reasonable basis for prosecution, may decide not to prosecute. However, the non-prosecution decision made by the Grand Jury does not fall within the "prohibition of double dangers." In certain cases, a grand jury may be formed separately or reexamined by an independent prosecutor.

The law of Missouri also sets the standard of "reasonable grounds" for grand jury decisions. And if 9 out of 12 grand jury members agree to prosecution, it can be then decided. In other words, as long as 4 jurors consider that there is not enough evidence, "potential defendants" should not be prosecuted and not tried by the courts. 2

\subsection{The Standard of Self-Defense}

The law allows everyone to use lethal force for their own protection under certain circumstances, and the law recognizes the use of deadly force by the police in certain situations. In order to investigate the Grand Jury's investigation and determination of Wilson's case, it is necessary to clarify the following substantive and procedural norms that are quite fundamental.

\subsubsection{Self-Defense: Ordinary People}

Under the law of Missouri, the basic element of the justification of personal justification for individuals is the reasonable belief that they have been subjected to unlawful attacks and the

\footnotetext{
${ }^{1}$ The Missouri Statutes, §540.320.

${ }^{2}$ Article I, Section 16 of the Missouri Bill of Rights.
} 
reasonable belief that it is necessary to use force to protect themselves. When protecting an individual from death, serious bodily injury or violent crime, and individual considers that there is a need to use deadly force, they shall use deadly force. 3 Whether a defense is justified or not depends on whether the individual is "the first aggressor," and secondly, to examine whether there is "reasonably believe."

\subsubsection{Self-Defense: Law Enforcement Officer's Use of Force in Making an Arrest}

A law enforcement officer in effecting an arrest or in preventing an escape from custody is justified in using deadly force only:

- When such is authorized under other sections of this chapter; or

- When he reasonably believes that such use of deadly force is immediately necessary to effect the arrest and also reasonably believes that the person to be arrested

$>$ Has committed or attempted to commit a felony; or

$>$ Is attempting to escape by use of a deadly weapon; or

$>$ May otherwise endanger life or inflict serious physical injury unless arrested without delay.4

In addition, the Ferguson Police Regulation on the Use of Force by Police Constables states that police officers shall not use lethal force unless they reasonably believe that their actions are to preserve their lives, including their own lives.5

\subsubsection{Burden of Proof}

According to Missouri's jurisprudence and law, defendants who defend themselves with justifiable defense should advocate the legitimate defense of the law. If the defendant claims that it is a legitimate defense and states the fact that it meets the legitimate defense conditions stipulated by law, the prosecution should bear the burden of proof in that the defendant does not meet such requirements. If the evidences can not rule out reasonable doubt, the defendant is not guilty. 6

\section{EVIDENCE AND JUDGMENT}

The grand jury in Wilson's case must consider whether there is a reasonable basis for Wilson's use of deadly force as a police officer or whether Wilson exercises ordinary people's right to self-defense in the context of this case. As a result, thousands of pages of testimony and key points have been disclosed in the report, which can be summarized as follows:

\subsection{Is Brown an attacker?}

Determining an attacker is of great importance in Missouri's law of self-defense, because an attacker, as a first-time attacker or threat-attacker, has no right to self-reliance on force for counterattacking. This means that in a round of fighting, the use of force by attackers is not a legitimate defense.7 However, the identity of the attacker is also likely to change: when the original attacker withdraws from the battle and clearly states that he wants to end the battle, if the other party insists on using it or threats of force, the original attacker will not bear the "attacker" identity, he also regained the right to self-defense. In Wilson's case, whether Brown can be considered as an attacker depends on the existence or non-existence of two key facts, namely, take the gun through violence and surrender.

\subsubsection{Take the Gun through Violence?}

Comprehensive physical evidence and witness testimony show that Brown and Wilson have disputes, and Brown had used violence in an attempt to snatch Wilson's pistol.

There is a certain contradiction between the witness's description of this dispute. In Wilson's testimony, Wilson said that when he was about to open the door, Brown severely closed the door and

\footnotetext{
${ }^{3}$ Use of force in defense of persons. Missouri Revised Statutes (M.R.S.) 563.031.

${ }^{4}$ Law enforcement officer's use of force in making an arrest. Missouri Revised Statutes (M.R.S.) 563.046.

${ }^{5}$ The City of Ferguson Police Department's use of force policy, section 410.01.

${ }^{6}$ Use of force in defense of persons. Missouri Revised Statutes (M.R.S.) 563.031.

STATE of Missouri v. James ANTHONY, 319 S.W.3d 524, Mo.App. S.D.,2010.

${ }^{7}$ Use of force in defense of persons. Missouri Revised Statutes (M.R.S.) 563.031.
} 
pulled his upper body into the car and whacked his face. Then Brown grabbed his gun and he tried to break free from the trigger and fired two shots while he pulled the trigger.8 Several witnesses made it clear that Brown put his body into the police car and boxed Wilson. Many witnesses said that while they heard the gunfire, Brown still had half a body inside the police car. However, at least one witness said that Brown never put any part of his body inside the car and that the shootings took place outside the car.9

Other evidence confirms his gun-taking in the car. First, Brown's blood (or DNA) was detected on the door of the police car, on Wilson's collar and on Wilson's pistol. Wilson's description of Brown's robbery process basically coincided with the results of this survey. However, some witnesses said that the direct flight between Brown and Wilson after their conversations clearly contradicted the findings.10 Second, a bullet fired from the Wilson gun was found in the cab, a gun fired in the car that hit the armrest inside the door in a downward angle. The location and angle of the bullet holes also confirm the gun-grabbing process described by Wilson. Thirdly, a medical examination of Wilson showed that his face was red and swollen, indicating that Wilson's face was indeed injured, as can be seen in the photo of Wilson after the haircut.

Brown's autopsy report basically confirms the existence of close competition. At the discretion of the medical examiner, there was a bullet bruise on Brown's right thumb, which was the only gunshot wound on Brown's body that was shot at close range. The shotgun that fired the bullet was estimated to be only 6 inches to 9 inches (equivalent to about $15.2 \mathrm{~cm}$ to $22.9 \mathrm{~cm}$ ). $11 \mathrm{In}$ addition, medical examiners think this bruise should taken in the first place in the overall sequence of the Brown gunshot wounds.12 So if Brown did not fight for firearms, why Brown's right hand would be so close shot, it is difficult to explain.

\subsubsection{Has Brown Surrendered Before being Shot?}

It was controversial whether Brown had been back to Wilson before falling to the ground after leaving the police car to run east, or whether he had raised his hand to surrender. Because if Brown had been back to Wilson all the time, whether running away or stand still, all showed that Brown had withdrawn from the battle and no longer posed a threat to Wilson's life or body; if Brown raised his hand and surrendered, it even made it clear that he no longer had an attacker Identity. Considering both the physical evidence and witness testimony, it can prove that Brown has surrendered.

Brown's autopsy report showed that it suffered a frontal shootout. Brown's autopsy report noted that neither Brown's body trunk nor his head gunshot wound was caused by a behind shot. One of the shootings on Brown's arm came from behind the shot, which was shot from the back of the right forearm into the body.13 In particular, the doctor pointed out that although the bullet was injected from the back of the right forearm, taking into account the possibility of human elbow movement, the concrete actions can not be estimated.14 The report actually states that except for a single shot that could not be determined whether it was shooting from behind or not, all the other gunshot wounds on Brown's body came from a frontal shot.

But it not sure if Brown has raised his hands and surrendered. Wilson's testimony firmly demonstrated that Brown did not surrender his hand. This is also supported by some eyewitnesses.15 On the other hand, in the testimony that Brown raised his hand, ${ }^{16}$ there were disagreements about the details of the height of Brown's hand and the specific posture of the hand. Still a few witnesses did not see this

\footnotetext{
${ }^{8}$ Grand Jury Testimony, Volume 5, Page 209-214.

${ }^{9}$ Statement of St. Louis Prosecuting Attorney Robert P. McCulloch.

${ }^{10}$ Statement of St. Louis Prosecuting Attorney Robert P. McCulloch.

${ }^{11}$ Grand Jury Testimony, Volume 3, Page 118.

${ }^{12}$ Grand Jury Testimony, Volume 3, Page 197.

${ }^{13}$ Grand Jury Testimony, Volume 3, Page 198.

${ }^{14}$ Grand Jury Testimony, Volume 3, Page 133.

${ }^{15}$ Grand Jury Testimony, Volume 6, Page 166-167.

${ }^{16}$ Grand Jury Testimony, Volume 17, Page 25 ; Grand Jury Testimony, Volume 16, Page 60 ; Grand Jury Testimony, Volume 8, Page 148.
} 
stage or have vague impression. Therefore, if Brown expressed his surrender to Wilson, it is necessary to examine it in combination with other evidence. However, Brown's other actions also shows that Brown has no intention of surrender.

\subsection{Does Wilson Reasonably Believe His Life is Threatened?}

Under Missouri's law, a person who wants to use force in justifiable defense must reasonably believe that he is in imminent danger of harm. As for the use of deadly force to defend, confine itself to the immediate danger of a person believing it in danger of death or serious bodily injury, and to have the reasonable belief that the use of force of sufficient fatal force is necessary for self-protection. Among them, the term "reasonable belief" refers to the belief that there is a reasonable basis for such beliefs to be made by rational people in the same situation. So, "reasonable to believe" depends on how the fact occurs, depends on the subjective perception, and does not depend on whether this belief eventually become a reality.17 In Wilson's case, considering the subjective and objective conditions, Wilson may have a reasonable basis if he believes his own life is threatened.

\subsubsection{Brown's Actions after Turning Back}

As Brown stopped in the corner of Canfield and Coppercreek, he turned back and faced Wilson. There was almost no dispute about this fact. However, there are many explanations for Brown's following actions. One witness used "full charge" to describe Brown's actions.18 One witness's words were somewhat moderated, namely "charge".19 There are witnesses that consider Brown's actions were not fast enough to be a charge.20 A witness said Brown "picked up a little bit of speed".21 There is a witness said that Brown is just "casually walking." 22 The spot investigation is clear that after Brown gotshot, he was still approaching Wilson.Because Brown's blood found 25 feet east of Brown's body.23 So, at least, after Brown's turning back,he still moved over more than seven meters in the direction of Wilson.

\subsubsection{Some Objective Facts}

Brown's lack of possession of weapons is not synonymous with Brown's lack of danger and threat. In fact, the balance of power between the two can also be seen from a comparison of their stature Wilson, weighing 210 pounds, while Brown is 292 pounds. And Brown's boxing and gun-taking by the police car seem to have the impact to make Wilson feeling threatened.

\subsubsection{Wilson's Subjective Feelings}

In Wilson's testimony, it was mentioned more than once that he felt his life threatened. For example, when it comes to the bridge robbery, Wilson said, "I feel if this person get my gun, he will kill me."24 Another example, Wilson describes Brown, "his face looks like a devil, I can only describe how angry he was."25 As for Brown's turn, Wilson said "he (Brown) rushed straight to me." "I know he'll kill me if he approaches me." 26

\subsection{Does Wilson's Self-Defense Exceed the Necessary Limit?}

Wilson fired a total of ten shots from his exit until Brown fell to the ground, hitting Brown's right arm, his right chest, his forehead and his head a total of 6 to 7 guns. Therefore, there may be doubt that if Wilson needs to conduct such a degree of self-defense, which refers to the necessary limits of a justifiable defense.

\footnotetext{
${ }^{17}$ STATE of Missouri v. James ANTHONY, 319 S.W.3d 524, Mo.App. S.D.,2010.

${ }^{18}$ Grand Jury Testimony, Volume 6, Page166.

${ }^{19}$ Grand Jury Testimony, Volume 18, Page27; Grand Jury Testimony, Volume 11, Page118.

${ }^{20}$ Grand Jury Testimony, Volume 12, Page44.

${ }^{21}$ Grand Jury Testimony, Volume 23, Page137.

${ }^{22}$ Grand Jury Testimony, Volume 11, Page151.

${ }^{23}$ Statement of St. Louis Prosecuting Attorney Robert P. McCulloch.

${ }^{24}$ Grand Jury Testimony, Volume 5, Page 214.

25Grand Jury Testimony, Volume 5, Page 225.

26Grand Jury Testimony, Volume 5, Page 229.
} 
However, Brown's blood distribution shows that Brown is still approaching Wilson after shoots. More importantly, the last shot had hit on Brown's head, and this last shot was exactly the one that caused Brown to lose his ability to move. Alone the other gunshot wounds will not cause people incapacitated, even if the combination of several shots after the injury is not enough. This actually shows that if Wilson does not shoot Brown's head, Brown may still pose a threat.

\subsection{Review and Decision}

\subsubsection{The Grand Jury}

Grand jury members who tried Wilson's case were chosen in May 2014, the shootings were not happened at that time. Among its 12 members, seven men and five women are included. In racial makeup, the grand jury has nine white and three black people, basically in line with the proportion of white and black population in St. Louis.

However, the operation of the grand jury in Wilson's case is somewhat different from the prevailing practice: in terms of duration, the grand jury usually adjudicates cases for no more than one day, whereas the Wilson case handled three months and 25 days; In the case of witnesses, the number of witnesses investigated by grand juries was usually small, and the potential defendants were not allowed to testify in front of a grand jury. The grand jury in Wilson heard testimony from 60 witnesses including Wilson's testimony. In the procedural secrecy issues, the grand jury process is not publicized. But for this case, prosecutor McCulloch released some evidence and witness testimony. 27

\subsubsection{Assess the Credibility of Testimony}

An important task for the grand jury hearing Wilson's case is to assess the credibility of the testimony of about 60 witnesses. On the one hand, it examines the contradictions or contradictions between testimony and physical evidence. After all, physical evidence is more objective than witness testimony. On the other hand, it examines the consistency and consistency of witness testimony, which is an important criterion for assessing the credibility of testimony and even the credibility of witnesses. The common method is to compare the testimony with the previous statements.

However, some witnesses in Wilson's case testimony is more credible, the most typical is Brown's companion (Johnson), who testified that Brown has surrendered. But Brown's body from the most eastern part of the blood obviously reflects the Brown still moved to Wilson after being shot. In addition, there were inconsistencies in the witness's own statements. From the statement made by the prosecutor McCulloch, some witnesses claimed before the results of the autopsy that they had seen several shots fired toward Brown's back, while others said that Wilson shoot the back of Brown while he was running away. However, the autopsy report showed that Brown did not suffer the underlying assault, after which no witness re-testified. Several witnesses also amended their storyline in a followup survey, while others have admitted that they simply did not witness anything and merely repeated their hearsay or hypothetical circumstances. 28

\subsubsection{No Prosecution Decision}

It is known to warrant Brown as an assailant based on the requirement of justifiable defense of the use of lethal force against ordinary people, and there is no reasonable basis for overthrowing Wilson's sense of threat and the need to kill him. If it were based on the police's use of lethal force for justifiable defense, it was known that Brown was guilty of a second-degree robbery (a serious felony) when he was violently robbed at a convenience store and that Wilson had "known to have committed a major crime ". Combined with all the evidence, the Missouri grand jury found "No probable cause exists" to sue Wilson and made a non-prosecution decision.

\section{COMments}

\subsection{The Diversion Function of Grand Jury}

Missouri's law requires that the prosecution to prove that Wilson was not concerned with his own life, as he said in his testimony. For this proof, reasonable doubt should be excluded, which make this

\footnotetext{
27 "What Happened in Ferguson?", The New York Times. November 25, 2014.

${ }^{28}$ Statement of St. Louis Prosecuting Attorney Robert P. McCulloch.
} 
proof extremely difficult. This is the current law of Missouri and the background to the Grand Jury's decision. Obviously, on the basis of the available evidence, the case will end up with a verdict of innocence if it go through court trial. Therefore, the Grand Jury's non-prosecutorial ruling equates the early announcement of the result.

The power of the Grand Jury to examine is to prevent abuse of public prosecutors' rights and to exclude some cases that are not eligible for prosecution, so as to protect citizens from unfounded prosecutions. In order to avoid the significant negative publicity caused to innocent people, there are often similar procedural diversion litigation mechanisms in criminal lawsuits in civil law countries as well as common law countries, such as the pre-trial procedure.

\subsection{The Unity of Substantive Interests and Procedural Interests}

From the point of view of the structure of interest, an overall interest entity includes two parts: the procedural interest and the substantive interest. Both of them are the intrinsic part of the interest entity. The entity is the unity of the procedural interests and the substantive interests. And for the exercise of the legitimate defender, it not only needs to safeguard its substantive interests, but also should be protected from being procedurally unfair, that is, to be defendants from being tried by the court.

Because on the one hand, the procedure itself is often a major punishment. The intensity of that punishment causes the arrested person and the court to ignore the opportunities offered in formal adversarial proceedings. Such "punishments" may include monetary and material losses, mental worries such as accepting complaints, debating debates and public trials, and may also include the negative impacts of future social activities. All of these can be significant issues for citizens.

On the other hand, the costs of producing justice have to influence our choice of behavior in terms of the actual cost of the program and the opportunity cost. In fact, expanding rights and remedies can have the opposite effect. Not only does this create more rules that completely neglected in reality, but also give the public a principled appearance of the decision-making process, which actually is nothing more than a proposition for a ritual theater without real content.

Thus, the complexity of a procedural path leading to the rights and interests of entities are likely to make seeming justice. Such a procedure is by no way to be justified. Perhaps some scholars think that things have their own objective laws of development and the procedure is just the same. Since our procedures are far from adequate in terms of refinement and standardization, why should we talk about extravagance and frugality? At the very least, however, we should give due attention to the right of innocent people that tried by the courts. We should als be vigilant against the act of violating the procedural rights of the parties in the name of "substantive justice."

\subsection{The Pressure of Public Opinion and the Independence of the Trial}

In essence, the application of law in Wilson's case is not a new problem, nor can it even be a major or complex legal issue. The tricky part is actually the social impact of the case. Under the tremendous pressure of public opinion, the grand jury also made a decision that obviously caused riots. Although the U.S. law does provide that prosecutors and grand juries must not, under any circumstances, violate the spirit of the judiciary due to public pressure. However, such independence is supported by judicial confidence and judicial credibility. The U.S. judge once said: "We are not correct because of authority, but because of authority." Even if one does not have an extreme understanding of the status of authority, it is undeniable that the basic bottom line in judicial credibility is that judicial authority is respected.

In fact, such cases of social impact that arise from the parties' appeals and media exaggerations are also common in China. The public's spontaneous or directed behavior often presupposes what kind of results can be regard as "justice." The case has not yet been brought to trial, all kinds of "facts" have been disseminated. And how to rule out the judgments of forensic "trial", how to withstand pressure to "sentence", is still a hard problem. Especially in criminal proceedings, after the decision not to prosecute "possible defendants", the prosecutor is highly possible to be subject to multiple doubts of the victims and the public media. However, bringing individuals to trial just because of public's anger will cause more harms. Judicial credibility should not a simply catering "public opinion", especially 
taking the uncertainty and controllability of "public opinion" into consideration.Moreover, judicial credibility is not based on the parties' reactions. All in all, if there is no judicial confidence, how comes the judicial credibility?

Citation: $O U$ Yuanjie,. " The Right to be Free from Trial: Comments on "State of Missouri V. Darren Wilson"'" International Journal of Humanities Social Sciences and Education (IJHSSE), vol 4, no. 12, 2017, pp. 140-148. doi: http://dx.doi.org/10.20431/2349-0381.0412018.

Copyright: () 2017 Authors. This is an open-access article distributed under the terms of the Creative Commons Attribution License, which permits unrestricted use, distribution, and reproduction in any medium, provided the original author and source are credited. 